medRxiv preprint doi: https://doi.org/10.1101/2021.06.07.21258508; this version posted June 11, 2021. The copyright holder for this preprint

(which was not certified by peer review) is the author/funder, who has granted medRxiv a license to display the preprint in perpetuity.

This article is a US Government work. It is not subject to copyright under 17 USC 105 and is also made available for use under a CCO license.

\title{
Prescribed footwear and orthoses are not prophylactic in preventing lower extremity injuries in military tactical athletes. A systematic review with meta-analysis.
}

Scott L. Paradise, MD ${ }^{1,2,3}$

scott.1.paradise.mil@mail.mil

Joshua R. Beer, DO ${ }^{1,4}$

joshua.r.beer.mil@mail.mil

Chris A. Cruz, MD ${ }^{5}$

chris.a.cruz.mil@mail.mil

Ken M. Fechner, MD ${ }^{1,5}$

kenneth.m.fechner.mil@mail.mil

Andrew J. MacGregor, PhD, MPH ${ }^{6}$

andrewmacgregor@protonmail.com

John J. Fraser, PT, DPT, PhD, FACSM ${ }^{1,6}$

email: john.j.fraser8.mil@mail.mil, ORCID: 0000-0001-9697-3795, Twitter: @NavyPT

1. Primary Care Sports Medicine Fellowship, Naval Hospital Camp Pendleton, Oceanside, CA, USA

2. United States Navy Medicine Readiness and Training Command Guam, Agana, GU, USA

3. Uniformed Services University of the Health Sciences, Bethesda, MD, USA

4. United States Navy Medicine Readiness and Training Unit, Marine Corps Recruit Depot

Parris Island, Parris Island, SC, USA

5. United States Navy Medicine Readiness and Training Command Camp Pendleton, Oceanside, CA, USA

6. Directorate for Operational Readiness \& Health, Naval Health Research Center, 140 Sylvester Road, San Diego, CA, USA

*Correspondence to: Scott L. Paradise, PSC 455, Box 208, Department of Orthopaedics, FPO, AP 96540; 671-488-5011; scott.1.paradise.mil@mail.mil

Disclaimer: The authors are military service member or employees of the U.S. Government.

This work was prepared as part of their official duties. Title 17, U.S.C. $§ 105$ provides that copyright protection under this title is not available for any work of the U.S. Government. Title 
medRxiv preprint doi: https://doi.org/10.1101/2021.06.07.21258508; this version posted June 11, 2021. The copyright holder for this preprint (which was not certified by peer review) is the author/funder, who has granted medRxiv a license to display the preprint in perpetuity.

This article is a US Government work. It is not subject to copyright under 17 USC 105 and is also made available for use under a CCO license.

17, U.S.C. $§ 101$ defines a U.S. Government work as work prepared by a military service member or employee of the U.S. Government as part of that person's official duties. The views expressed in this article are those of the authors and do not necessarily reflect the official policy or position of the Department of the Navy, Department of Defense, nor the U.S. Government. 
medRxiv preprint doi: https://doi.org/10.1101/2021.06.07.21258508; this version posted June 11, 2021. The copyright holder for this preprint (which was not certified by peer review) is the author/funder, who has granted medRxiv a license to display the preprint in perpetuity.

This article is a US Government work. It is not subject to copyright under 17 USC 105 and is also made available for use under a CCO license.

2 Introduction: Military members are exposed to high cumulative physical loads that frequently

3 lead to injury. Prescribed footwear and orthoses have been used to prevent injury. The purpose of

4 this systematic review with meta-analysis was to assess if prescribed prophylactic footwear or

5 foot orthoses reduced lower extremity injury risk in military tactical athletes.

6 Methods: MEDLINE, Embase, Web of Science, CINAHL, SportDiscus, and DTIC databases

$7 \quad$ were searched for randomized controlled trials published at any time that compared foot orthoses

8 or prescribed footwear (to include shock-absorbing insoles and socks) to a placebo intervention

9 or a no-treatment control. Methodological quality was assessed and numbers of injuries,

10 population at risk, and the duration of the study epoch were extracted and relative risk (RR)

11 calculated. An omnibus meta-analysis was performed assessing all prescribed footwear and

12 orthoses intervention studies, with subgroup analyses conducted on studies with similar

13 interventions [i.e., basketball athletic shoes; athletic shoes (prescribed by foot type); foot

14 orthoses; shock-absorbing insoles; socks; tropical combat boots].

15 Results: Of 1,673 studies identified, 22 studies were included. Three of eight studies that

16 employed orthoses demonstrated significantly reduced overuse injuries compared to no treatment

17 controls (RR range: 0.34-0.68); one study showed neoprene insoles significantly decreased

18 overuse injuries (RR: 0.75 ). There were no other significant effects in the individual studies, and

19 no protective effects observed in the omnibus meta-analysis or in the component sub analyses.

20 Conclusions: Prescribed footwear and orthoses do not appear to have a prophylactic effect on

21 lower quarter MSKI in military members and cannot be recommended at this time. 
medRxiv preprint doi: https://doi.org/10.1101/2021.06.07.21258508; this version posted June 11, 2021. The copyright holder for this preprint (which was not certified by peer review) is the author/funder, who has granted medRxiv a license to display the preprint in perpetuity.

This article is a US Government work. It is not subject to copyright under 17 USC 105 and is also made available for use under a CCO license.

\section{INTRODUCTION}

Musculoskeletal injuries (MSKI) are common during military training and operations and

25 can adversely affect medical readiness, warfighter performance, and mission accomplishment.

26 MSKI, primarily of the lower quarter, were leading reasons for outpatient medical encounters in

272019 in the Military Health System.[1,2] These injuries substantially contribute to medical-

28 related attrition and the multibillion per-annum direct and indirect healthcare cost for active

29 military members and veterans.[2] The etiology of many non-battle related MSKI are repetitive,

30 microtraumatic overuse injuries resulting from high intensity exercises and cumulative loads

31 incurred primarily during marching and running.[3,4] The substantial burden imposed by MSKI

32 warrants in-depth assessment of preventive interventions used to mitigate these injuries.

33 Foot orthoses, shock-absorbing insoles, and other prescribed footwear have been used for

34 the prevention of overuse injuries in athletes and military recruits.[5-7] These interventions alter

35 lower quarter biomechanics by attenuating ground reaction forces, distributing plantar pressures,

36 and altering kinematics during functional tasks.[5,8-10] However, there is mounting scrutiny

37 regarding the effectiveness of footwear prescription for running-related prophylaxis.[11] While

38 prescribed orthoses or footwear may mediate potential intrinsic risk factors, such as foot

39 phenotype, this does not necessarily translate to reduction of injury. With the types and volume

40 of exposure, unique hazards, and a "mission first" culture unique to the military that precludes

41 care-seeking,[12] it is unclear whether prophylactic orthoses or prescribed footwear would be

42 effective in MSKI prophylaxis in this unique population.

43 The physical demands placed on military tactical athletes during training are inherently

44 different than those incurred by their civilian counterparts. Military members are exposed to high 
medRxiv preprint doi: https://doi.org/10.1101/2021.06.07.21258508; this version posted June 11, 2021. The copyright holder for this preprint (which was not certified by peer review) is the author/funder, who has granted medRxiv a license to display the preprint in perpetuity.

This article is a US Government work. It is not subject to copyright under 17 USC 105 and is also made available for use under a CCO license.

45 cumulative physical loads resulting from frequent and high intensity training, often with little

46 respite. Given the unique exposures specific to the military, it is unclear whether foot orthoses,

47 shock-absorbing insoles, or prescribed footwear would be protective against MSKI. While prior

48 systematic reviews have evaluated whether prophylactic footwear or ankle-foot orthosis

49 prescription were able to reduce injury in the civilian population, $[6,7,14]$ none at the time of

50 writing have evaluated MSKI prophylaxis in the military specifically. Therefore, the purpose of

51 this systematic review with meta-analysis was to assess if prescribed prophylactic footwear or

52 foot orthoses reduced lower extremity injury risk in military tactical athletes.

\section{METHODS}

The protocol for this study was registered a priori in PROSPERO (CRD42020183403,

56 http://bit.ly/CRD42020183403). The Preferred Reporting Items for Systematic Reviews and

57 Meta-Analyses (PRISMA)[15] and A MeaSurement Tool to Assess systematic Reviews version

582 (AMSTAR 2)[16] were used to guide study reporting.

\section{Eligibility Criteria}

60 Studies were eligible for inclusion if they were randomized controlled trials that

61 compared foot orthoses or prescribed footwear (to include shock-absorbing insoles and socks) to

62 a placebo intervention or a no-treatment control. All studies must have reported the inclusion of

63 military tactical athletes, the burden (number, rate, or proportion) of lower extremity injuries for

64 both the intervention and control groups, the at-risk population size, and the duration of the study

65 epoch. If the required information could not be ascertained from the published study, the

66 corresponding authors were contacted. Studies were excluded if they were systematic reviews or 
medRxiv preprint doi: https://doi.org/10.1101/2021.06.07.21258508; this version posted June 11, 2021. The copyright holder for this preprint (which was not certified by peer review) is the author/funder, who has granted medRxiv a license to display the preprint in perpetuity.

This article is a US Government work. It is not subject to copyright under 17 USC 105 and is also made available for use under a CCO license.

67 retrospective studies, if the interventions were not randomized, or if the data was not available

68 for extraction.

69 Search Strategy

70 A research librarian was consulted to develop the search strategy. The search strategy,

71 comprised of MeSH terms, is detailed in the Supplemental Table 1 (https://doi.org/XXXXXXX).

72 The searches were limited to records in English, the native language of the study team, published

73 at any time of inquiry. MEDLINE, Embase, Web of Science, CINAHL, SportDiscus, and the

74 Defense Technical Information Center (DTIC) databases were queried on January 10, 2020.

75 DTIC (https://discover.dtic.mil/) serves as the research repository of the U.S. Department of

76 Defense. Records were organized and duplicates were removed using Rayyan QCRI, an

77 application used to facilitate study selection for systematic reviews (https://rayyan.qcri.org/).

78 Two reviewers (SLP and JB) independently reviewed each record by title and then abstract for

79 inclusion. A third author (KF) resolved any disagreements. Study selection is detailed in the

80 PRISMA flowsheet (Figure 1).

\section{Data Extraction}

82 Two reviewers (SLP and JRB) independently assessed each report for extractable data using the

83 Cochrane Collaboration Data Collection Form for RCTs and non-RCTs. The number of injuries,

84 the number of the population at risk, and the duration of the study epoch were extracted. Studies

85 that reported incidence or prevalence measures were reverse calculated to extract count data.

86 Study characteristics pertaining to participant demographics, trial setting, method of

87 randomization, and intervention characteristics are reported in Supplemental Table 2

88 (https://doi.org/XXXXXXX). Any disagreements were resolved by consensus. If consensus

89 could not be achieved, a third author (KF) resolved any disagreements. Cumulative incidence of 
medRxiv preprint doi: https://doi.org/10.1101/2021.06.07.21258508; this version posted June 11, 2021. The copyright holder for this preprint (which was not certified by peer review) is the author/funder, who has granted medRxiv a license to display the preprint in perpetuity.

This article is a US Government work. It is not subject to copyright under 17 USC 105 and is also made available for use under a CCO license.

90 lower quarter MSKI for both intervention and control groups were calculated using the number

91 of injuries during the study epoch and the population size at the time of allocation. Calculations

92 of relative risk with $95 \%$ confidence intervals (CI), attributable risk (AR), and number needed to

93 treat (NNT) were used to assess prophylactic effects for each study.

\section{Risk of Bias Assessment}

95 Risk of bias for each study were assessed using the Cochrane Collaboration tool.[17]

96 Each study was assessed in seven domains: random sequence generation, allocation

97 concealment, blinding of participants and personnel, blinding of outcome assessment, incomplete

98 outcome data, selective outcome reporting, and other. Each domain was independently rated by

99 two authors (SLP and JRB) as high risk of bias, low risk of bias, or marked as unclear.

100 Reviewers resolved disagreements by consensus, and a third author (KF) was consulted to

101 resolve disagreements if needed. A study was judged to have overall high risk of bias if at least

102 one domain was rated as having high risk, or if there were concerns in multiple domains that

103 substantially lowered confidence in its results.[17]

\section{Synthesis Methods}

An omnibus meta-analysis was performed assessing all prescribed footwear and orthoses

106 intervention studies, with subgroup analyses conducted on studies with similar interventions

107 [athletic shoes (basketball); athletic shoes (prescribed by foot type); foot orthoses; shock-

108 absorbing insoles; socks; tropical combat boots]. Pooled outcomes were calculated using the

109 Mantel-Haenszel method with the Hartung-Knapp adjustment for random effects models.[18,19]

110 Heterogeneity was assessed using the $I^{2}$ and $\chi^{2}$ statistics and conclusions were contextualized

111 according to risk of bias. $I^{2}$ statistics were interpreted as suggested by Higgins and colleagues,

112 with higher values indicating greater heterogeneity.[20] A leave-one-out sensitivity analysis and 
medRxiv preprint doi: https://doi.org/10.1101/2021.06.07.21258508; this version posted June 11, 2021. The copyright holder for this preprint (which was not certified by peer review) is the author/funder, who has granted medRxiv a license to display the preprint in perpetuity.

This article is a US Government work. It is not subject to copyright under 17 USC 105 and is also made available for use under a CCO license.

113 Baujat plot[21] were used to diagnose specific studies contributing to heterogeneity. Reporting

114 bias was assessed with a funnel plot and Egger's statistic to evaluate symmetry. Data synthesis

115 was performed using the 'meta' package (version 4.18-0) for R version 4.0.3 (The R Foundation

116 for Statistical Computing, Vienna, Austria).

\section{RESULTS}

\section{Study Selection}

120 The search strategy yielded 1673 records after duplicates were removed (Figure 1). Four

121 additional records were identified through cross-referencing citations.[22-25] Of these, 39 full-

122 text records were assessed for eligibility, and 22 included in the systematic review. Three studies

123 were excluded as these were not randomized intervention trials.[26-28] Simkin et al.[29] and

124 Finestone et al.[30] met inclusion criteria, however they were extensions of the studies

125 conducted by Milgrom et al. in 1985[31] and 1992[30], respectively, and were excluded.

126 Sherman et al. [32] was included in the systematic review but excluded from the meta-analysis

127 because the study epoch was not specified. Mundermann et al.[22] was included in the

128 systematic review but excluded from the meta-analysis due to insufficient data.

\section{Study Characteristics}

130 Supplemental Table 2 (https://doi.org/XXXXXXX) details the extracted study

131 characteristics that include the setting, population at risk, intervention, comparison, time at risk,

132 and injury outcome of interest. Eight studies evaluated the effect of biomechanical orthoses on

133 overuse injury incidence in military recruits.[10,31,33-38] Six studies evaluated the effect of

134 shock-absorbing inserts.[9,22,25,32,39,40] One study evaluated the effect of shock-absorbing

135 heel cups with and without heel-cord stretches.[24] Six studies evaluated the prophylactic effect 
medRxiv preprint doi: https://doi.org/10.1101/2021.06.07.21258508; this version posted June 11, 2021. The copyright holder for this preprint (which was not certified by peer review) is the author/funder, who has granted medRxiv a license to display the preprint in perpetuity. This article is a US Government work. It is not subject to copyright under 17 USC 105 and is also made available for use under a CCO license.

136 of prescribed footwear,[30,41-45] and one study evaluated the effect of padded and double-

137 layered socks.[23]

138 Three trials employed cluster randomization to enhance participant blinding.[9,23,32]

139 The remaining trials randomized each participant. It was otherwise impossible for trials to

140 maintain blinding of orthosis or insert among military units who often live and train together in

141 close confines, so four studies made use of a sham insert to minimize bias.[9,10,34,40] Studies

142 included predominantly male participants (range: $56 \%$ to $100 \%$ ), a finding attributed to

143 conscription practices[37,38] or training site demographics.[44] Trials typically occurred over

144 the course of an initial recruit training course or initial period of service which ranged from 6

145 weeks[45] to 6 months.[38] Andrish et al.[24] specified only that training occurred over the

146 summer. Since "Plebe Summer" at the US Naval Academy is 7 weeks in duration, it was

147 assumed that this was the study duration. Sherman et al.[32] also did not specify the epoch

148 length, but did mention that it occurred during Army basic training that was 8 weeks long at the

149 time of the study.

150 Five studies described a protocol to confirm stress fractures or other injuries with the use

151 of radiographs[9,38] and Technetium bone scans.[30,31,34] One study confirmed stress fractures

152 with magnetic resonance imaging.[35] Bonanno et al.[10] was the only study that referenced a

153 previously published research protocol and specified use of standardized clinical assessments.

154 Three studies counted any injury severe enough to cause a limitation in training.[35,38,40] One

155 study required a limitation in training of at least one day,[39] and one study only counted injuries

156 severe enough to limit training for a period of three days.[33] The remaining studies either

157 specified a clinical exam by a healthcare provider or study team member, review of diagnostic

158 codes from a patient record, or did not specify diagnostic criteria.[22-25,32,36,37,41,41,43-45] 
medRxiv preprint doi: https://doi.org/10.1101/2021.06.07.21258508; this version posted June 11, 2021. The copyright holder for this preprint (which was not certified by peer review) is the author/funder, who has granted medRxiv a license to display the preprint in perpetuity.

This article is a US Government work. It is not subject to copyright under 17 USC 105 and is also made available for use under a CCO license.

\section{Risk of Bias Assessment}

161 were unclear or had high risk of bias. Four studies were rated as low risk in the majority of the

162 assessment categories.[10,37,38,44] Lack of blinding of participants, or the failure to report

163 blinding, was the primary threat to validity across the majority of studies. To a lesser extent,

164 uncertainty pertaining to blinding of outcome data due to lack of granularity in methodological

165 reporting was also common.[22-25,30-33,35,36,39-42] Finally, there were a considerable

166 number of trials that were rated as unclear or high risk of bias pertaining to allocation

167 concealment and random sequence generation.[9,22-25,30-34,39,41-43,45] Milgrom et al.[31]

168 observed substantial dropout in the orthosis intervention group (21.0\%) due to discomfort and

169 analyzed only the remaining participants, which posed a substantial source of attrition bias.

170 Esterman et al.[33] observed substantially low compliance in injured recruits introducing

171 differential bias, and was excluded from the meta-analysis.

\section{Study Findings}

\section{Orthoses}

174 Three of the eight studies that employed orthoses demonstrated significantly reduced

175 overuse injuries when compared to no treatment controls (RR range: 0.34 to 0.68$)$.[31,35,37]

176 Finestone et al.[34] reported a significant protective effect by combining semi-rigid

177 polypropylene and soft polyurethane intervention arms. When analyzed individually, both

178 polypropylene (RR: 0.59) and polyethylene (RR: 0.61$)$ orthoses had wide 95\% CIs that were

179 statistically non-significant. Lastly, the intervention group in the study conducted by Hesarikia et

180 al.[36] was approximately twice as likely to experience an injury while wearing orthoses 
medRxiv preprint doi: https://doi.org/10.1101/2021.06.07.21258508; this version posted June 11, 2021. The copyright holder for this preprint (which was not certified by peer review) is the author/funder, who has granted medRxiv a license to display the preprint in perpetuity.

This article is a US Government work. It is not subject to copyright under 17 USC 105 and is also made available for use under a CCO license.

181 compared to the no-treatment controls (AR: 14.2 per 1000 person-weeks, NNT Harm: 9). There

182 were no further significant findings in studies assessing prophylactic orthoses.

183 Shock-Absorbing Insoles

184 Two studies reported a reduction in overuse injuries in recruits provided with shock-

185 absorbing insoles compared to no treatment controls.[25,39] Of these, one study showed

186 neoprene insoles significantly decreased overuse injuries (RR: 0.75, NNT Benefit: 15), but not

187 stress fractures.[39] While Smith[25] reported improved injury rates for US Coast Guard recruits

188 who were provided either Spenco $(9.5 \%)$ or Poron $(8.7 \%)$ insoles compared to no treatment

189 controls (29.2\%), calculations of RR with 95\% CI using extracted data were non-significant

190 [Spenco: $0.29(0.06,1.26)$; Poron: $0.29(0.06,1.26)]$. There were no further significant findings

191 in studies assessing prophylactic insoles.

192 Prescribed Footwear

193 Studies of prescribed athletic footwear by arch height in military recruits reported no

194 significant effects.[43-45] However, our calculations of RR using extracted data suggest that the

195 prescribed footwear may have actually have had a significant, but small, increase in injury risk in

196 Air Force recruits (RR: 1.11, NNT Harm: 29).[45] In a study assessing prescribed tropical

197 combat boots compared to standard issue leather boot controls in Marine recruits, the

198 intervention group were reported to have significantly higher occurrence of retrocalcaneal

199 bursitis, but not other overuse injuries.[41] Calculations of RR based on overall injury

200 occurrence suggest no significant effect. In a follow-on study conducted with Army recruits,[42]

201 the intervention group that wore the tropical combat boot had significantly more injuries (RR:

202 1.39, NNT Harm: 17) than the standard leather boot control group.[42] In a study assessing the

203 prophylactic effects of padded polyester socks or a two-sock system (a thin, inner polyester sock 
medRxiv preprint doi: https://doi.org/10.1101/2021.06.07.21258508; this version posted June 11, 2021. The copyright holder for this preprint (which was not certified by peer review) is the author/funder, who has granted medRxiv a license to display the preprint in perpetuity.

This article is a US Government work. It is not subject to copyright under 17 USC 105 and is also made available for use under a CCO license.

204 worn under a thick, outer cotton-wool sock) compared to the standard issue uniform sock,

205 padded polyester socks prevented blisters (RR: 0.53, NNT Benefit: 3), an outcome the authors

206 used as a surrogate for knee joint overuse injury.[23]

\section{Results of Syntheses}

There were no significant protective effects observed in the omnibus meta-analysis or in

209 the component analyses assessing pooled effects of athletic shoes prescribed by foot type, foot

210 orthoses, shock-absorbing insoles, socks, or tropical combat boots compared to controls.

211 There was considerable heterogeneity observed in the omnibus synthesis (Figure 2). In the

212 subanalyses of similar interventions, heterogeneity ranged from low (shock absorbing insoles) to

213 substantial and considerable (foot orthoses, tropical boots). Subanalyses of interventions with the

214 highest degree of heterogeneity also had the fewest number of studies included (socks, tropical

215 boots), with exception of foot orthoses. While there were studies that contributed a substantial

216 degree of heterogeneity identified on the Baujat plot (Figure 3), the sensitivity analysis found

217 that omission of these studies would only minimally reduce total heterogeneity (Supplemental

218 Table 3, https://doi.org/XXXXXXXX).

\section{Reporting Bias}

220 Significant asymmetry was found in the Eggers test, which is visualized in the funnel plot

221 (Figure 4). At the apex of the funnel, there was greater symmetry in the studies with the lowest

222 standard errors. As standard error increased, it appears that there was bias toward studies that

223 demonstrated protective effects. 
medRxiv preprint doi: https://doi.org/10.1101/2021.06.07.21258508; this version posted June 11, 2021. The copyright holder for this preprint (which was not certified by peer review) is the author/funder, who has granted medRxiv a license to display the preprint in perpetuity. This article is a US Government work. It is not subject to copyright under 17 USC 105 and is also made available for use under a CCO license.

The primary finding of this study was that orthosis, insole, or footwear prescription did

227 not have a pooled prophylactic effect on lower quarter MSKI in military members. Since most of

228 the included studies that prescribed interventions did not consider the individual characteristics

229 or needs of the military member, the widespread application of the non-specific interventions

230 employed in these studies cannot be recommended at this time. Due to the substantial

231 heterogeneity and the risks of bias observed across the reviewed studies, these findings should be

232 interpreted based on the limitations of these trials.

233 Our findings agree with those reported by Knapik et al.[46], Yeung et al.[7], and Rome et

234 al.[6] that found inconclusive evidence for the use of prescribed orthoses, insoles, or footwear for

235 the prevention of injury. Among these studies, only the synthesis conducted by Knapik et al.[46]

236 employed a military-only study population in the aggregation of their previous three studies of

237 Army, Marine Corps, and Air Force recruits.[43-45] While our findings pertaining to prescribed

238 shock-absorbing insoles agree with the those found in the meta-analysis conducted by Bonanno

239 el al.,[14] our findings pertaining to the lack of prophylactic effects of foot orthoses diverge.[14]

240 Their analysis found that orthoses were effective in preventing overall MSKI. [14] In the meta-

241 analysis of injury type, this was found to be limited to stress fractures and not soft tissue

242 injuries.[14] The divergence in our findings may have been a result of combining all injuries

243 from each study prior to inclusion in the analyses.

244 From a clinical perspective, widespread and non-specific prescription of orthoses,

245 insoles, or footwear cannot be recommended at this time. Bullock et al.[3] similarly concluded

246 that there was insufficient evidence to recommend prescribed footwear based on arch height, the

247 use of shock-absorbing insoles, or replacement of footwear at regular intervals for the prevention

248 of injury. This should not be interpreted to preclude the utilization of these interventions for 
medRxiv preprint doi: https://doi.org/10.1101/2021.06.07.21258508; this version posted June 11, 2021. The copyright holder for this preprint (which was not certified by peer review) is the author/funder, who has granted medRxiv a license to display the preprint in perpetuity.

This article is a US Government work. It is not subject to copyright under 17 USC 105 and is also made available for use under a CCO license.

249 specific clinical indications identified during examination of trained medical professionals. From

250 a research perspective, our findings raise more questions than answers. There is a need for high

251 quality prevention studies using contemporary research methods, specifically those outlined in

252 the CONSORT guidelines.[47] Furthermore, it is unclear if policies such as the obligatory use of

253 Berry Amendment compliant shoes, which are regulated to be domestically manufactured and

254 issued based on foot type in US military recruits, $[48,49]$ has an effect on injury and warrants

255 future investigation.

256 There are limitations to this study. We utilized cumulative incidence measures at the time

257 of allocation for calculations of relative risk. While this measure is consistent with the intention

258 to treat principle, it does not account for attrition due to administrative reasons, which may have

259 biased the results. While it can be assumed there was equity in both groups leading to non-

260 differential bias, this is an assumption. We looked at overall injury burden and did not

261 investigate if these interventions were protective against specific types of injuries. It is plausible

262 that specific findings may have become non-significant by employing this approach. Lastly, we

263 used non-peer reviewed research reports to mitigate the effects of publication bias. While this

264 may have affected methodological quality of these studies, these studies[41,42] were not

265 dissimilar from other studies that were vetted by peer reviewers.

\section{CONCLUSIONS}

Prescribed footwear and orthoses do not appear to have a prophylactic effect on lower

269 quarter MSKI in military members. Since most of the included studies that prescribed

270 interventions did not consider the individual characteristics or needs of the military member, the

271 widespread application of the non-specific interventions employed in these studies cannot be 
medRxiv preprint doi: https://doi.org/10.1101/2021.06.07.21258508; this version posted June 11, 2021. The copyright holder for this preprint

(which was not certified by peer review) is the author/funder, who has granted medRxiv a license to display the preprint in perpetuity.

This article is a US Government work. It is not subject to copyright under 17 USC 105 and is also made available for use under a CCO license.

272 recommended at this time. These findings should be tempered based on the limitations of the

273 studies in this area.

274

275 Support

276 No external financial support was received for this study. We greatly appreciate the

277 assistance of Simona Konecna for her assistance in developing the search strategy and executing

278 the search.

279

$280 \quad$ Key Messages

281 - Musculoskeletal injury is common in military populations and leads to impaired medical

282 readiness and large financial costs.

283 - Prescribed footwear and orthoses have been proposed as measures for lower limb injury

284 prevention.

285 - In military populations, prophylactic footwear and orthoses do not appear to have a

286 preventive effect on lower limb injury rates.

287 - Future preventive studies should utilize high-quality, contemporary methodologies. 
medRxiv preprint doi: https://doi.org/10.1101/2021.06.07.21258508; this version posted June 11, 2021. The copyright holder for this preprint

(which was not certified by peer review) is the author/funder, who has granted medRxiv a license to display the preprint in perpetuity.

This article is a US Government work. It is not subject to copyright under 17 USC 105 and is also made available for use under a CCO license.

\section{REFERENCES}

2901 Smith HJ, Taubman SB, Clark LL, et al. Absolute and relative morbidity burdens attributable to various illnesses and injuries, active component, U.S. Armed Forces, 2019. Med Surveill

$292 \quad$ Mon Rep 2020;7.

2932 Grimm PD, Mauntel TC, Potter BK. Combat and Noncombat Musculoskeletal Injuries in the

294 US Military. Sports Med Arthrosc Rev 2019;27:84-91. doi:10.1097/JSA.0000000000000246

2953 Bullock SH, Jones BH, Gilchrist J, et al. Prevention of Physical Training-Related Injuries: Recommendations for the Military and Other Active Populations Based on Expedited Systematic Reviews. Am J Prev Med 2010;38:S156-81. doi:10.1016/j.amepre.2009.10.023

4 Edwards WB. Modeling Overuse Injuries in Sport as a Mechanical Fatigue Phenomenon. Exerc Sport Sci Rev 2018;46:224-31. doi:10.1249/JES.0000000000000163

3005 McMillan A, Payne C. Effect of foot orthoses on lower extremity kinetics during running: a systematic literature review. J Foot Ankle Res 2008;1:13. doi:10.1186/1757-1146-1-13

3026 Rome K, Handoll HHG, Ashford R. Interventions for preventing and treating stress fractures and stress reactions of bone of the lower limbs in young adults. Cochrane Database Syst Rev 2005;:CD000450. doi:10.1002/14651858.CD000450.pub2

7 Yeung SS, Yeung EW, Gillespie LD. Interventions for preventing lower limb soft-tissue running injuries. Cochrane Database Syst Rev 2011;:CD001256. doi:10.1002/14651858.CD001256.pub2

8 Totah D, Menon M, Jones-Hershinow C, et al. The impact of ankle-foot orthosis stiffness on gait: A systematic literature review. Gait Posture 2019;69:101-11. doi:10.1016/j.gaitpost.2019.01.020

9 Gardner LI, Dziados JE, Jones BH, et al. Prevention of lower extremity stress fractures: a controlled trial of a shock absorbent insole. Am J Public Health 1988;78:1563-7. doi:10.2105/AJPH.78.12.1563

10 Bonanno DR, Murley GS, Munteanu SE, et al. Effectiveness of foot orthoses for the prevention of lower limb overuse injuries in naval recruits: a randomised controlled trial. $\mathrm{Br}$ J Sports Med 2018;52:298-302. doi:10.1136/bjsports-2017-098273

31711 Malisoux L, Theisen D. Can the "Appropriate” Footwear Prevent Injury in Leisure-Time Running? Evidence Versus Beliefs. J Athl Train 2020;55:1215-23. doi:10.4085/1062-6050523-19 health perspectives to address short-term readiness and long-term health of military service members. Cardiopulm Phys Ther J 2020;31:22-8. doi:10.1097/CPT.0000000000000129 
medRxiv preprint doi: https://doi.org/10.1101/2021.06.07.21258508; this version posted June 11, 2021. The copyright holder for this preprint

(which was not certified by peer review) is the author/funder, who has granted medRxiv a license to display the preprint in perpetuity.

This article is a US Government work. It is not subject to copyright under 17 USC 105 and is also made available for use under a CCO license.

13 McLaughlin R, Wittert G. The obesity epidemic: implications for recruitment and retention of defence force personnel. Obes Rev 2009;10:693-9. doi:https://doi.org/10.1111/j.1467789X.2009.00601.X

14 Bonanno DR, Landorf KB, Munteanu SE, et al. Effectiveness of foot orthoses and shockabsorbing insoles for the prevention of injury: a systematic review and meta-analysis. $\mathrm{Br} \mathrm{J}$ Sports Med 2017;51:86-96.

15 Page MJ, McKenzie JE, Bossuyt PM, et al. The PRISMA 2020 statement: an updated guideline for reporting systematic reviews. BMJ 2021;372:n71. doi:10.1136/bmj.n71

16 Shea BJ, Reeves BC, Wells G, et al. AMSTAR 2: a critical appraisal tool for systematic reviews that include randomised or non-randomised studies of healthcare interventions, or both. $B M J$ 2017;358:j4008. doi:10.1136/bmj.j4008

17 Higgins JPT, Altman DG, Gøtzsche PC, et al. The Cochrane Collaboration's tool for assessing risk of bias in randomised trials. BMJ 2011;343:d5928. doi:10.1136/bmj.d5928

18 Mantel N, Haenszel W. Statistical aspects of the analysis of data from retrospective studies of disease. J Natl Cancer Inst 1959;22:719-48.

19 Aert RCM van, Jackson D. A new justification of the Hartung-Knapp method for randomeffects meta-analysis based on weighted least squares regression. Res Synth Methods 2019;10:515-27. doi:https://doi.org/10.1002/jrsm.1356

20 Higgins J, Churchill R, Chandler J, et al. Cochrane handbook for systematic reviews of interventions version 6.2. 0 (updated February 2021), Cochrane, 2021. Available Cochrane Community 2021.

21 Baujat B, Mahé C, Pignon J-P, et al. A graphical method for exploring heterogeneity in meta-analyses: application to a meta-analysis of 65 trials. Stat Med 2002;21:2641-52. doi:https://doi.org/10.1002/sim.1221

22 Mundermann A, Stefanyshyn DJ, Nigg BM. Relationship between footwear comfort of shoe inserts and anthropometric and sensory factors. Med Sci Sports Exerc 2001;33:1939-45.

23 Van Tiggelen D, Wickes S, Coorevits P, et al. Sock systems to prevent foot blisters and the impact on overuse injuries of the knee joint. Mil Med 2009;174:183-9.

24 Andrish JT, Bergfeld JA, Walheim J. A prospective study on the management of shin splints. J Bone Joint Surg Br 1974;56:1697-700.

25 Smith W, Walter J, Bailey M. Effects of insoles in coast guard basic training footwear. $J \mathrm{Am}$ Podiatr Med Assoc 1985;75. doi:10.7547/87507315-75-12-644

26 Finestone A, Novack V, Farfel A. A prospective study of the effect of foot orthoses composition and fabrication on comfort and the incidence of overuse injuries. Foot Ankle Int 2004;25. 
medRxiv preprint doi: https://doi.org/10.1101/2021.06.07.21258508; this version posted June 11, 2021. The copyright holder for this preprint

(which was not certified by peer review) is the author/funder, who has granted medRxiv a license to display the preprint in perpetuity.

This article is a US Government work. It is not subject to copyright under 17 USC 105 and is also made available for use under a CCO license.

27 Bensel CK. Effects of Four Sole Constructions for Combat Boots on Lower Extremity Injuries among Men and Women in US Army Basic Combat Training. Army Natick Research and Development Labs MA 2013.

28 Milgrom C, Sorkin A, Gam A, et al. The search for the best infantry boot. Disaster Mil Med 2016;2. doi:10.1186/s40696-016-0024-5

29 Simkin A, Leichter I, Giladi M, et al. Combined Effect of Foot Arch Structure and an Orthotic Device on Stress Fractures. Foot Ankle 1989;10:25-9. doi: $10.1177 / 107110078901000105$

30 Finestone A, Shlamkovitch N, Eldad A, et al. A prospective study of the effect of the appropriateness of foot-shoe fit and training shoe type on the incidence of overuse injuries among infantry recruits. Mil Med 1992;157:489-90. doi:10.1093/milmed/157.9.489

31 Milgrom C, Giladi M, Kashtan H, et al. A Prospective Study of the Effect of a ShockAbsorbing Orthotic Device on the Incidence of Stress Fractures in Military Recruits. Foot Ankle 1985;6:101-4. doi:10.1177/107110078500600209

32 Sherman R, Karstetter K, May H, et al. Prevention of lower limb pain in soldiers using shock-absorbing orthotic inserts. J Am Podiatr Med Assoc 1996;86:117-22. doi: $10.7547 / 87507315-86-3-117$

33 Esterman A, Pilotto L. Foot Shape and Its Effect on Functioning in Royal Australian Air Force Recruits. Part 2: Pilot, Randomized, Controlled Trial of Orthotics in Recruits with Flat Feet. Mil Med 2005;170:629-33. doi:10.7205/MILMED.170.7.629

34 Finestone A, Giladi M, Elad H, et al. Prevention of Stress Fractures Using Custom Biomechanical Shoe Orthoses: Clin Orthop 1999;360:182-90. doi:10.1097/00003086199903000-00022

35 Franklyn-Miller A, Wilson C, Bilzon J, et al. Foot Orthoses in the Prevention of Injury in Initial Military Training: A Randomized Controlled Trial. Am J Sports Med 2011;39:30-7. doi: $10.1177 / 0363546510382852$

36 Hesarikia H, Nazemian SS, Rasouli HR, et al. Effect of Foot Orthoses on Ankle and Foot Injuries in Military Service Recruits: A Randomized Controlled Trial. Biosci Biotechnol Res Asia 2014;11:1141-8. doi:10.13005/bbra/1499

37 Larsen K, Weidich F, Leboeuf-Yde C. Can custom-made biomechanic shoe orthoses prevent problems in the back and lower extremities? A randomized, controlled intervention trial of 146 military conscripts. J Manipulative Physiol Ther 2002;25:326-31. doi:10.1067/mmt.2002.124419

38 Mattila VM, Sillanpää PJ, Salo T, et al. Can orthotic insoles prevent lower limb overuse injuries? A randomized-controlled trial of 228 subjects: Prevention of lower limb overuse injuries. Scand J Med Sci Sports 2011;21:804-8. doi:10.1111/j.1600-0838.2010.01116.x 
medRxiv preprint doi: https://doi.org/10.1101/2021.06.07.21258508; this version posted June 11, 2021. The copyright holder for this preprint

(which was not certified by peer review) is the author/funder, who has granted medRxiv a license to display the preprint in perpetuity.

This article is a US Government work. It is not subject to copyright under 17 USC 105 and is also made available for use under a CCO license.

394

395

396

397

398

399

400

401

402

403

404

405

406

407

408

409

410

411

412

413

414

415

416

417

418

419

420

421

422

423

39 Schwellnus MP, Jordaan G, Noakes TD. Prevention of common overuse injuries by the use of shock absorbing insoles: A prospective study. Am J Sports Med 1990;18:636-41. doi:10.1177/036354659001800614

40 Withnall R, Eastaugh J, Freemantle N. Do shock absorbing insoles in recruits undertaking high levels of physical activity reduce lower limb injury? A randomized controlled trial. $J R$ Soc Med 2006;99:32-7. doi:10.1258/jrsm.99.1.32

41 Bensel CK. The effects of tropical and leather combat boots on lower extremity disorders among US Marine Corps recruits. Army Natick Research and Development Labs MA 1976.

42 Bensel CK, Kish RN. Lower extremity disorders among men and women in Army basic training and effects of two types of boots. Army Natick Research and Development Labs MA 1983.

43 Knapik JJ, Swedler DI, Grier TL, et al. Injury reduction effectiveness of selecting running shoes based on plantar shape. $J$ Strength Cond Res 2009;23:685-97.

doi:10.1519/JSC.0b013e3181a0fc63

44 Knapik JJ, Trone DW, Swedler DI, et al. Injury reduction effectiveness of assigning running shoes based on plantar shape in marine corps basic training. Am J Sports Med 2010;38:175967. doi:10.1177/0363546510369548

45 Knapik JJ, Brosch LC, Venuto M, et al. Effect on Injuries of Assigning Shoes Based on Foot Shape in Air Force Basic Training. Am J Prev Med 2010;38:S197-211. doi:10.1016/j.amepre.2009.10.013

46 Knapik JJ, Trone DW, Tchandja J, et al. Injury-Reduction Effectiveness of Prescribing Running Shoes on the Basis of Foot Arch Height: Summary of Military Investigations. $J$ Orthop Sports Phys Ther 2014;44:805-12. doi:10.2519/jospt.2014.5342

47 Schulz KF, Altman DG, Moher D. CONSORT 2010 statement: updated guidelines for reporting parallel group randomised trials. Trials 2010;11:1-8.

48 Fox C. Letter to Representative Tsongas from the Acting Deputy Secretary of Defense pertaining to Berry amendment-compliant athletic shoes for recruits. 2014.

49 Platzer MD. Athletic Footwear for the Military: The Berry Amendment Controversy. 2016. https://www.everycrsreport.com/reports/IN10501.html (accessed 8 May 2021). 
Table 1. Risk of bias assessment for included studies

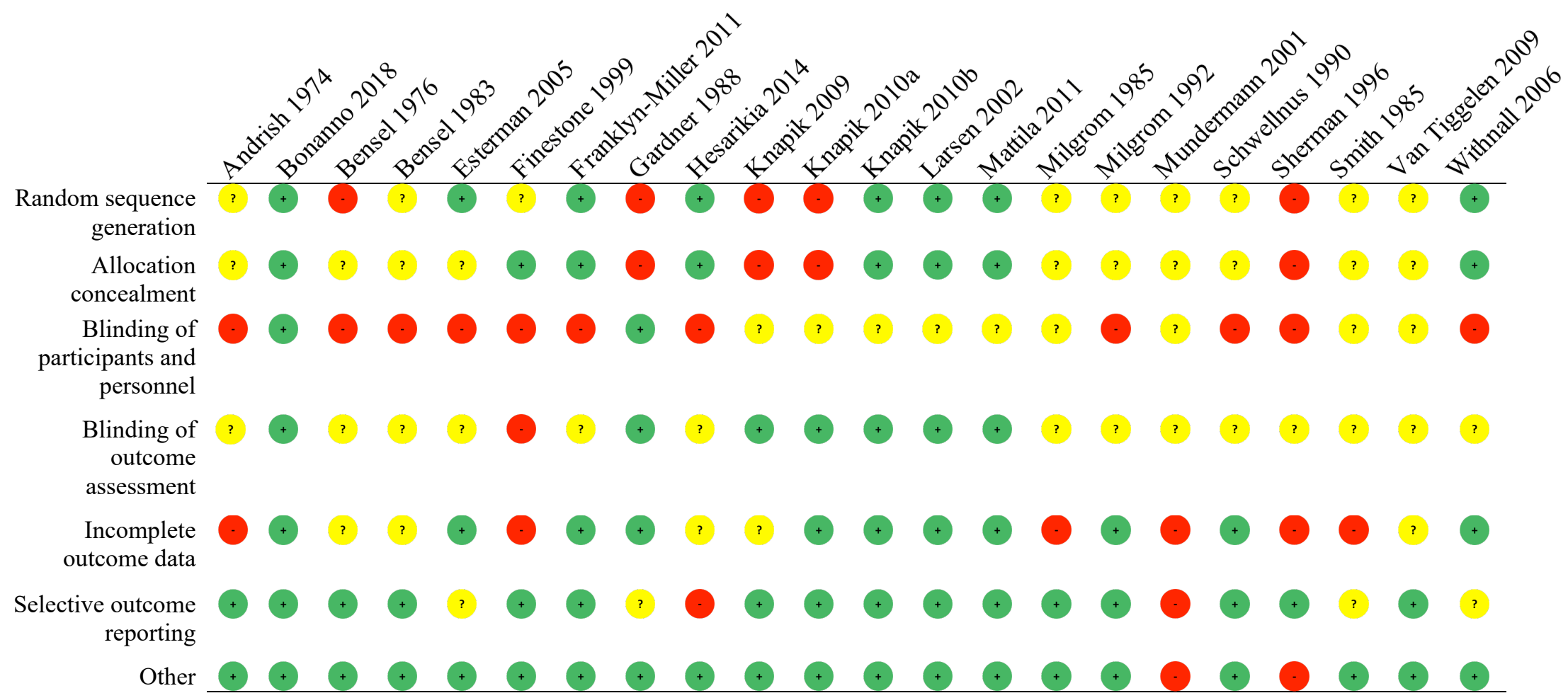


medRxiv preprint doi: https://doi.org/10.1101/2021.06.07.21258508; this version posted June 11, 2021. The copyright holder for this preprint (which was not certified by peer review) is the author/funder, who has granted medRxiv a license to display the preprint in perpetuity.

This article is a US Government work. It is not subject to copyright under 17 USC 105 and is also made available for use under a CCO license.

Figure 1. PRISMA flow diagram of study selection process. CINAHL, Cumulative Index of Nursing and Allied Health Literature; DTIC, Defense Technical Information Center.

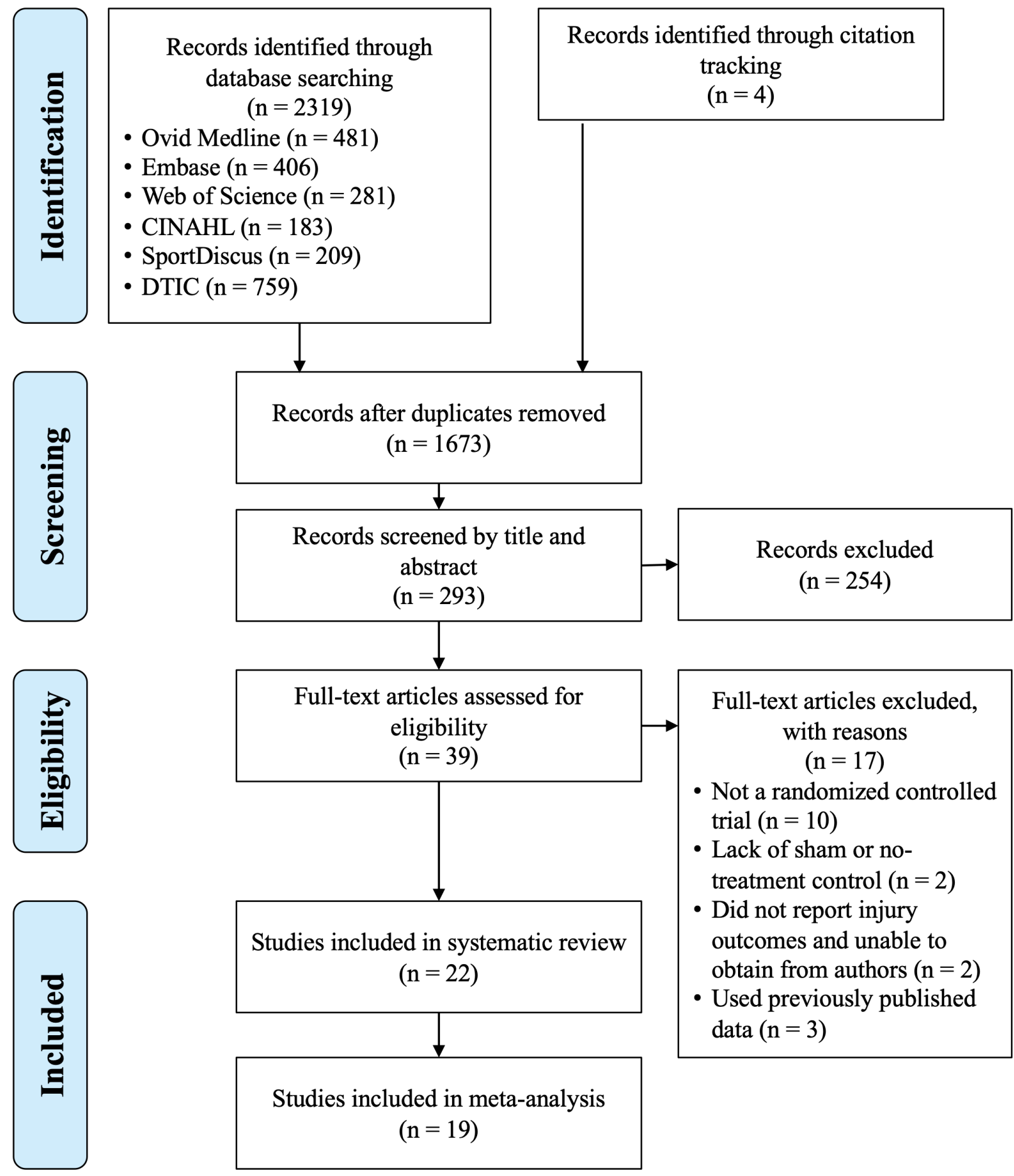


medRxiv preprint doi: https://doi.org/10.1101/2021.06.07.21258508; this version posted June 11, 2021. The copyright holder for this preprint

(which was not certified by peer review) is the author/funder, who has granted medRxiv a license to display the preprint in perpetuity.

This article is a US Government work. It is not subject to copyright under 17 USC 105 and is also made available for use under a CCO license.

Figure 2. Meta-analyses of lower extremity injuries by intervention

Subgroup

Athletic shoes (Basketball)

Milgrom 1992

Random effects model

Prediction interval

not applicable

Athletic shoes (Prescribed based on arch height)

Knapik 2009

Knapik 2010a

Knapik 2010b

Random effects model

Prediction interval

$I^{2}=46 \%[0 \% ; 84 \%], \chi_{2}^{2}=3.7(p=0.16)$

Foot orthosis

Bonanno 2018

Finestone 1999 (Semirigid)

Finestone 1999 (Foam)

Franklyn-Miller 2011

Hesarikia 2014

Larsen 2002

Mattila 2011

Milgrom 1985

Random effects model

Prediction interval

$I^{2}=86 \%[75 \% ; 93 \%], \chi_{7}^{2}=51.37(p<0.01)$

Shock-absorbing insoles Andrish 1974 (Heel pads alone)

Andrish 1974 (Heel pads \& calf stretching)

Gardner 1988

Schwellnus 1990

Withnall 2006 (Sorbothane)

Withnall 2006 (Poron)

Smith 1985 (Poron)

Smith 1985 (Neoprene)

Random effects model

Prediction interval

$I^{2}=37 \%[0 \% ; 72 \%], \chi_{7}^{2}=11.19(p=0.13)$

\section{Socks}

Van Tiggelen 2009 (Padded socks)

Van Tiggelen 2009 (Double socks)

Random effects model

Prediction interval

$I^{2}=67 \%[0 \% ; 93 \%], \chi_{1}^{2}=3.03(p=0.08)$

\section{Tropical combat boots}

Bensel 1976

Bensel 1983

Random effects model

Prediction interval

$I^{2}=85 \%[38 \% ; 96 \%], \chi_{1}^{2}=6.54(p=0.01)$

Fixed effects (plural) model

Prediction interval

$I^{2}=79 \%[69 \% ; 86 \%], \chi_{5}^{2}=8.32(p=0.14)$
Risk Ratio

RR $95 \%-\mathrm{Cl}$

$0.93 \quad[0.85 ; 1.01]$

$0.93[0.85 ; 1.01]$

$1.02 \quad[0.94 ; 1.11]$

$1.11 \quad[1.00 ; 1.24]$

$0.95 \quad[0.84 ; 1.07]$

$1.03[0.85 ; 1.24]$

$[0.40 ; 2.63]$

$0.68 \quad[0.44 ; 1.04]$

$0.59 \quad[0.25 ; 1.37]$

$0.61 \quad[0.26 ; 1.41]$

$0.34 \quad[0.22 ; 0.54]$

$1.98 \quad[1.37 ; 2.87]$

$0.82 \quad[0.71 ; 0.96]$

$1.22[0.89 ; 1.68]$

$0.50 \quad[0.35 ; 0.71]$

$0.75[0.47 ; 1.20]$

$[0.20 ; 2.83]$

$1.47 \quad[0.83 ; 2.62]$

$1.02[0.56 ; 1.85]$

$1.00 \quad[0.78 ; 1.28]$

$0.76 \quad[0.58 ; 0.99]$

$0.97 \quad[0.72 ; 1.30]$

$1.11 \quad[0.83 ; 1.48]$

$0.29 \quad[0.06 ; 1.26]$

$0.29 \quad[0.06 ; 1.26]$

$0.91[0.64 ; 1.30]$

[0.30; 2.74]

$0.52 \quad[0.35 ; 0.78]$

$0.83 \quad[0.60 ; 1.13]$

0.67 [0.04; 11.85]

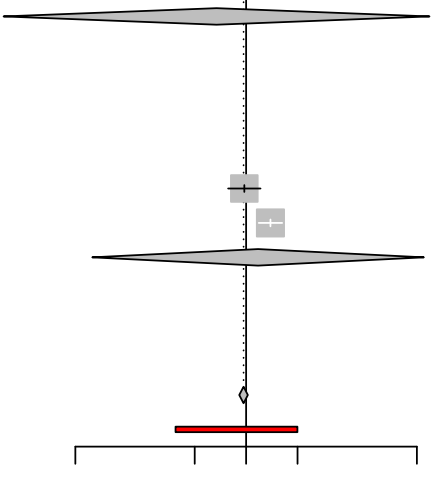

$0.98 \quad[0.78 ; 1.21]$

$1.39 \quad[1.19 ; 1.63]$

1.17 [0.13; 10.99]

$0.97[0.91 ; 1.02]$

$[0.39 ; 2.00]$ 
Figure 3. Baujat plot of study heterogeneity.

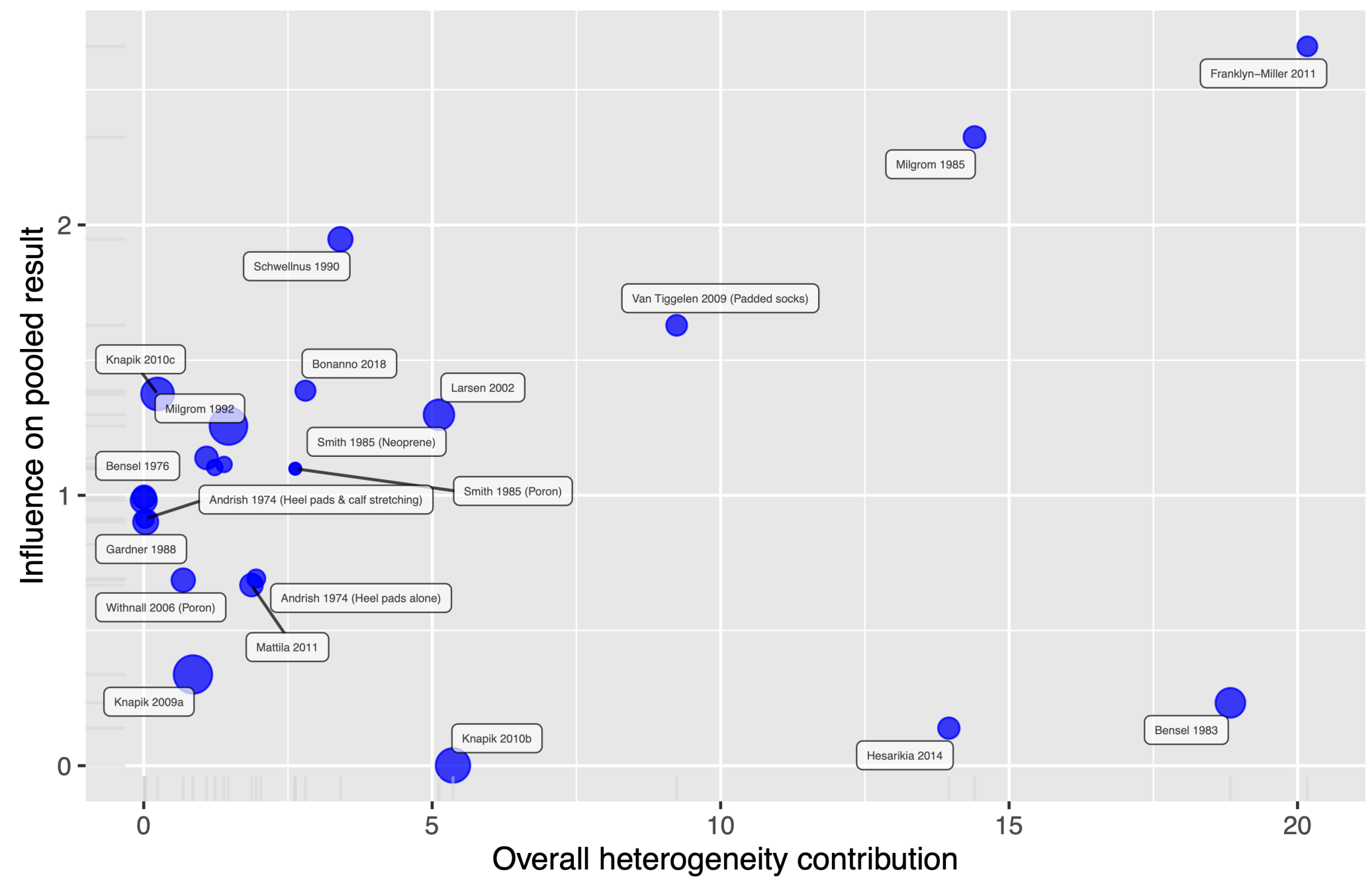


Figure 4. Funnel plot assessing reporting bias.

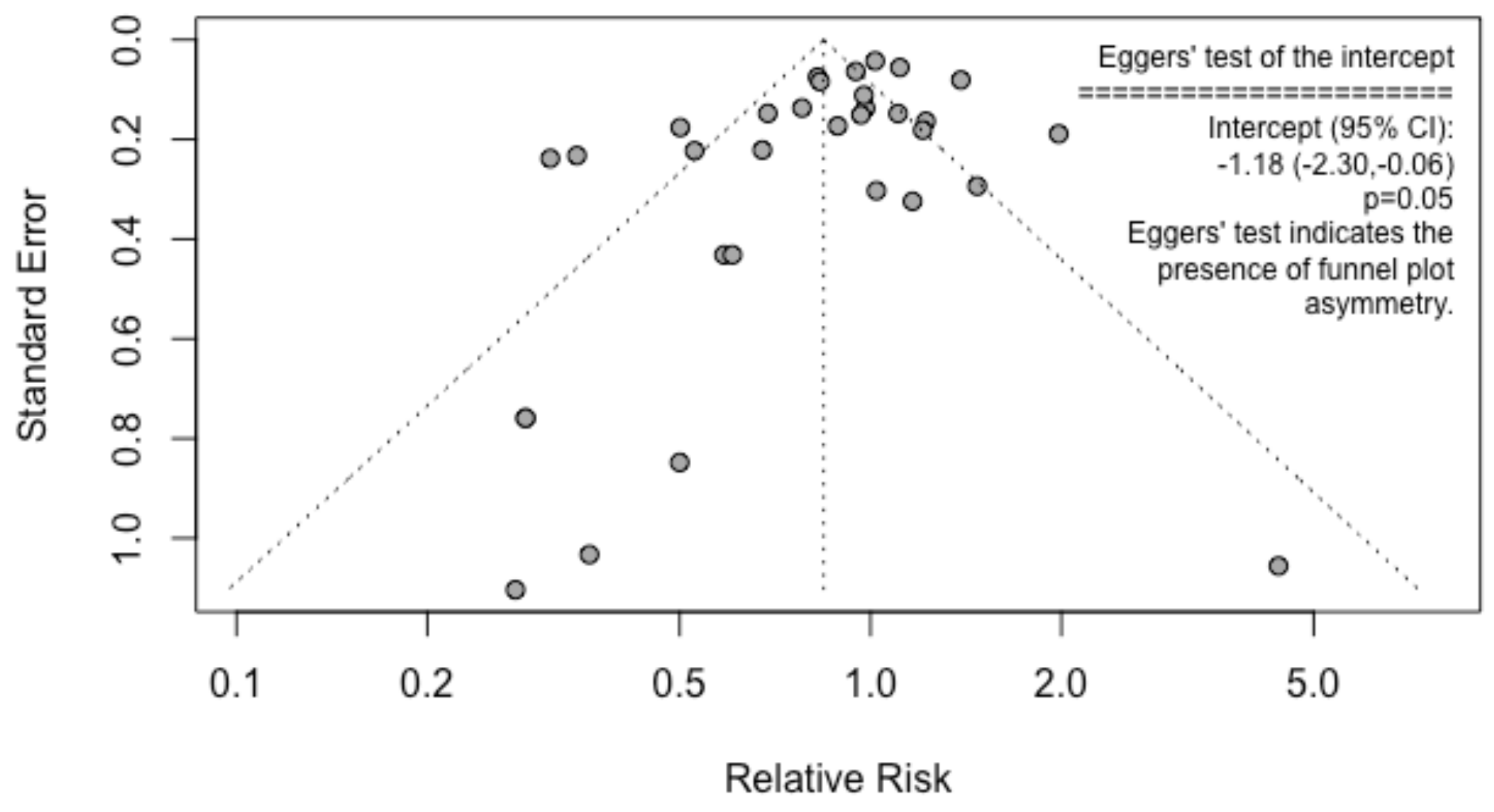

